\title{
Living in the climate crisis: Exploring situated perspectives and openings for change through everyday life stories
}

Nina Moesby Bennetsen, PhD fellow, Doctoral School of People and Technology, Roskilde University

Stories and narratives have been used in social scientific research to include perspectives of lived experiences in different contexts. In this article, I argue that everyday life stories of situated experiences can contribute with rich understandings of different experiences, possibilities for change, or abilities to respond to the climate crisis. The article is based on theories from within urban studies, everyday life sociology, feminist theory and scholars engaged with stories in in social sciences.

\section{Introduction}

During the summer of 2018, a number of countries in the Northern hemisphere, among these Denmark, experienced a heat wave that lasted several months. A recent study from Eidgenössische Technische Hochschule Zürich concludes that the simultaneous occurrences of heat waves across the Northern hemisphere in 2018, were caused by human activity (Rüegg 2019). In European countries, the consequences of the widespread heat wave included deaths, infrastructural damages, and forest fires. The consequences were less extensive in Denmark, but during these months of increased temperatures, exceptionally many hours of sun and a rainfall well below the monthly average of the summer months (Danish Meteorological Institute 2018), we felt, saw, smelled, heard, and tasted a hitherto unfamiliar version of summer. The heat wave was one of many experienced changes. During and after this and similar occurrences, we experience and tell stories of the consequences of human impact on the Earth. How the changed climate is experienced and storied by people, and what we can learn about possibilities for change or response from these stories, are the questions that led to this article.

In the decade since COP15, scientists, media, and some politicians have generated attention to climate change and its global impact. Much climate change research is rooted 
in natural science, and the figures, models, and measurements presented seem separate from the lived, social lives (Eskjær and Sørensen 2014; Bee, Rice and Trauger 2015; Freudendal-Pedersen and Kesselring 2018). In a recent article, Nielsen and Bislev argue that a central question for researchers engaged with climate change is how to engage politicians and citizens in climate change (Nielsen and Bislev 2018), and others argue for a humanistic climate change research that study how people understand and present climate change (Sørensen and Eskjær 2014). One way of addressing this is to explore how the climate crisis is experienced and storied in everyday life. The point of this is not to explore ways to place further responsibilities on individuals, as current climate change policies have been criticised of doing (e.g. Bee, Rice and Trauger 2015), but to explore everyday life understandings that may connect situated understandings to the existing research on climate change. With a background in transdisciplinary urban studies, I find it essential to study the everyday life aspect of cities and societies, as these situated experiences hold perspectives of irrationalities and conflicts, that are not quantifiable.

In this theoretically based article, I argue that focusing attention on the stories of the lived, situated experiences of everyday life opens up for richer understandings of the experiences, possibilities for change, or abilities to respond to the climate crisis. The aim with this article is to conduct a theoretical conceptualisation of different insights that everyday life stories may bring, about openings for change to social science dealing with climate change research. The article is based on theoretical works from within urban studies, everyday life sociology, feminist theory and scholars engaged with stories in in social sciences. First, I present an overview of theoretical arguments for studying everyday life and stories in social sciences. Following this, I present a conceptualisation of the different openings for change that everyday life stories may contribute with. I have developed the conceptualisation on the basis of my work with stories in social science, as I discovered that the differences of the openings have to do with different possibilities for change in the climate crisis. The conceptualization is based on international research literature within urban studies, drawing on examples from Copenhagen that emphasize the importance of context. The current article is theoretical, and as such, it aims to show how stories can be used in social scientific research on climate change rather than to tell the stories. I focus on the everyday life perspective and the stories related to the everyday situated experiences of the climate crisis and openings for change. Others have written reviews on narratives and stories of different scales in energy and climate change research (e.g. Moezzi, Janda and Rotmann 2017). 
Everyday life stories

Everyday life as site of social scientific research

Before focusing on the importance of stories in climate change research, I will outline the argument for everyday life as a site of social scientific research. Understanding the everyday experiences of living in the current climate crisis concerns life in rural, suburban and urban settings. In this article, I focus on the lived experiences of the climate crisis in urban surroundings, since an increasing number of people live in cities. Due to the density of cities, environmental issues occur more concentrated here, and cities hold potentials for solutions, when the issues are visible and can be recognised as issues (Spirn 1984).

Life in the city and the city as a phenomenon transcends traditional disciplines, but reaches disciplines such as sociology, anthropology, political science, economy, ethnography, and geography. One point of reference of the city is to understand the city as part of complex social, political, cultural, geographical, and technological networks, as it is understood in the transdisciplinary field of mobilities research (Urry 2000; Graham and Marvin 2001; Freudendal-Pedersen and Kesselring 2018). Mobilities research helps us understand that local and global movements of people, information, and goods, and the unintended consequences that follow, make up the conditions of cities, the social life within them and societies in a broader sense (Urry 2000; Sheller and Urry 2006; Urry 2007; Beck 2009; Freudendal-Pedersen and Kesselring 2018). One of the unintended consequences of the increased movement is climate change (Beck 2009; Urry 2011).

Climate change and climate change policies are not detached from social lives, but situated in everyday life (Bee, Rice and Trauger 2015). Mobilities researchers have pointed to the importance of everyday life perspectives in urban studies due to the complexities, ambivalences, and irrationalities of everyday life (Urry 2007; e.g. FreudendalPedersen 2009; Hartmann-Petersen 2009). Focusing the lens on everyday life in cities emphasises the understanding that the climate crisis is a social and cultural, as well as environmental, economic or technical matter (Egmose 2015), and that climate change research must accommodate the different perspectives.

Understanding and being aware of the significance of everyday life experiences is of importance to social scientists and to practitioners, politicians and others engaged in understanding the social dynamics of cities and societies and possible avenues for change. Despite its often mundane and unspectacular character, everyday life contains important insights to the experiences of society and urban life, since this is where power relations, politics, societal norms and activist practices are acted out every day (Bech-Jørgensen 1994; Pink 2012; Bee, Rice and Trauger 2015). Further insights may occur when connecting macroscale global processes, power relations, and political movements to the microscale knowledge of everyday life, as it is in everyday life that knowledge, action and experience is lived and is ascribed meaning (Rose 1997; Bee, Rice and Trauger 2015). 
An everyday life focus in climate research does not provide one universal answer to how the climate crisis is experienced but may contribute with nuances of how we as researchers understand the complex and differentiated social life in the climate crisis. The argument is that knowledge is produced, situated and particular, rather than universal (Haraway 1988; Rose 1997), and that there is a need to take into account the particularities of everyday life in social scientific research on climate change or sustainability: "It is through a theory of practice and place that we can comprehend the material, social, sensory and mediated environments of which everyday life, activism and thus processes through which sustainability might be achieved, all form a part" (Pink 2012, 13). Everyday life is situated in relation to specific environments and surroundings. However differently experienced in different surroundings, living with the climate crisis is a condition for contemporary everyday life, and studying how this condition is experienced, managed and storied brings further insights to climate change research and openings for change.

What defines everyday life has been discussed by many, and Bech-Jørgensen writes that everyday life "...cannot be defined in sociological terms. Everyday life can be described as the life we recreate and reproduce every day. What can be defined, I propose, are the conditions of everyday life and the ways in which these conditions are handled" (Bech-Jørgensen 1994, 291). Thus, everyday life studies may focus on the activities, relations, and processes that create and recreate everyday life, and everyday life is a processual rather than substantial concept (Bech-Jørgensen 1994). Pink writes that everyday life is "... where we make our worlds and where our worlds make us" (Pink 2012, 5). This reciprocity between everyday life and its surroundings and conditions means that everyday life can be the venue for change towards sustainability. Everyday life is then a site of activism in the reciprocal relations between the everyday actions and the streams of influence from the wider society and the interconnected networks in and between local contexts such as the home, the neighbourhood, the community or the city (Pink 2012).

Everyday life is often characterised by predictability and routines that make up parts of our daily lives, as ways of navigating without inventing our world anew every day. Changes are, however, also an inevitable part of everyday life on different scales (Bech-Jørgensen 1994), whether these happen due to external events or are developed as everyday activism (Pink 2012). Meaning-making is an essential part of everyday life as meaning-making processes become a way of navigating predictability as well as changes (Bech-Jørgensen 1994).

One way of understanding the meaning-making processes in everyday life, is through studying the stories we tell. Studying the stories of everyday life creates openings for exploring the meaning-making processes of everyday life in the climate crisis, the storying of what is taken for granted and what could be different. Social scientists studying climate change may find further insights into how we make sense of the climate crisis; this simultaneously abstract and specific risk, by exploring the stories that are told about climate crisis and perhaps find avenues for change through these stories. 
Why everyday life stories matter

The importance of stories, narratives, and language has been stated in social sciences for decades (Clandinin 2016). This has been presented through the narrative turn in social sciences (Denzin 2001), and more specifically for urban studies the argumentative turn in planning (Fischer and Forester 1993), and the communicative turn in planning theory (Healey 1993). These turns in planning theory and social sciences acknowledge that language and communication shape the way we live and understand the world (Fjalland, Freudendal-Pedersen and Hartmann-Petersen 2017). For urban scholars, the stories of lived experiences in the city offer valuable insights as stories "... can often provide a far richer understanding of the human condition, and thus of the urban condition, than traditional social science, and for that reason alone, deserve more attention" (Sandercock 2003,12 ). I argue that the stories of everyday life experiences are of equal importance for social scientists studying the climate crisis. Stories, narratives, and storytelling are important for understanding and communicating our experiences, ideas of the world and abilities to respond to the climate crisis (Freudendal-Pedersen 2014; Gibson, Rose and Fincher 2015; Freudendal-Pedersen and Kesselring 2016; Fjalland 2019). The climate crisis is a 'messy' problem to which a clear-cut and solely technical solutions seems difficult to imagine due to its complexity (Fischer and Gottweis 2012). What everyday life stories can bring to climate research is a questioning of "... what counts and matters, and whose stories are told, and how and why. Regarding this, a question of representation, of storytelling, is therefore of significance because the way our stories are composed reflects realities" (Fjalland 2018, 6). Everyday life stories provide insights into living in the climate crisis and the situated experiences that nuances the scientific or political framing of the climate crisis, by studying what stories are retold, by whom and what stories are silenced. Everyday life stories are in this way not a replacement for natural scientific research on climate change. Rather, the perspective from everyday life stories offer nuances to the messy problem and take part in an interdisciplinary approach to the climate crisis (Freudendal-Pedersen and Kesselring 2016).

What, then, is a story and what makes it a story? There seems to be little agreement among social scientists about this. Clandinin and Connelly write that a story “... is a portal through which a person enters the world and by which their experience of the world is interpreted and made personally meaningful" (Connelly \& Clandinin 2006, 375, in Clandinin 2016, 13). This echoes the argument that stories may enrich the understandings of situated experiences and the meaning-making processes of everyday life but serves less help in understanding what actually makes a story.

Some social scientists find a story to be made up by linearity, explanatory strength, and a structured framework. Here, a story consists of a framework, a sense of coherence, a potential for generalisability, recognisable conventions such as a structure or protagonists, and a moral tension (Sandercock 2003). This view on stories echoes the Aristotelian understanding of story having a beginning, a middle, and an end (Le Guin 2007). This 
linearity resembles the idea of a story that we know from fiction such as films and literature. Fjalland writes about the view of the story as linear, straight, and simple that "... it restricts what can be told, how it can be told, who it can involve, and what matters and is considered meaningful. This restricts the use of stories as methods as this may limit the analytical and communicative sensitivities" (Fjalland 2019, 60).

Other social scientists present another view on what makes a story, namely that “...stories are continuously unfolding accounts, whose extensions move in many directions" (Gubrium and Holstein 2009, 228). In this sense, everyday life stories are not fixed or linear with defined structures. Rather, they are ongoing and complex and they evolve concurrently with the storyteller's surroundings and circumstances. When studying everyday life stories, researchers are always entering and researching "in the midst" of the lived experiences (Clandinin 2016). The view of a story as something other than a linear narrative helps us as researchers to understand the ongoing storying in everyday life and that everyday life stories do not always lead to one interpretation. Working with stories from this view implies becoming attentive to the multiple, complex and differentiated experiences of everyday life, and becomes "...less about finding themes and more about asking what stories do, which is to inform human life" (Frank 2012, 2). What then, are the stories being told in everyday life in the climate crisis, and what might social sciences learn from the situated stories? The study of stories and narratives will not lead to complete and universal answers, but perhaps to wonderings, imaginings, and curiosity (Clandinin 2016).

\section{Understandings of lived experiences through stories}

Social scientists from various disciplines have engaged with stories in everyday life is through narrative inquiry, an approach "...to the study of human lives conceived as a way of honouring lived experience as a source of important knowledge and understanding" (Clandinin 2016, 17). In newer studies of narrative inquiry, emphasis is placed on the lived experiences, how they are narrated through stories, and how stories construct meaning-making of the world over time through communication with others (Paschen and Ison 2014; Clandinin 2016; Chase 2018). Everyday life stories may provide richer insights into embodied, situated experiences and are important data sources as they construct reality rather than mirror reality (Paschen and Ison 2014). Meaning is constructed and negotiated, through the living, telling, retelling, and reliving of stories and as experiences change over time, so do stories, since they are seen as processes rather than objects (Clandinin 2016). This means that narrative inquirers understand "...experience as a relational matter, changing over time, through various interactions with other human beings and the physical surroundings" (Clandinin 2016, 14), and that these situated interactions are embedded in the different contexts that they appear in (Chase 2018). Narrative inquirers are engaged in how “...people interpret the world from their specific social, historical, 
and cultural locations and is concerned with the diversity of voices and worldviews represented through narratives" (Paschen and Ison 2014, 1086).

Narrative inquiry seeks to understand experiences of human lives, and as the research is engaged in situated, embodied experiences, the "...knowledge developed from narrative inquiries is textured by particularity and incompleteness - knowledge that leads less to generalizations and certainties (Clandinin \& Murphy, 2007) and more toward wondering about and imagining alternative possibilities (Bateson, 2000)" (Clandinin 2016, 52). In this sense, experience is understood as more than what is possible to represent in the written representation of research articles, and representation always involves selection (Clandinin 2016). This calls for researchers to be reflexive and perform ethnographic sensibility that “...opens up questions about the circumstances under which certain stories get told (or don't get told) in everyday life, what narrators (whether people or organizations) are doing in relation to various audiences as they tell their stories, and the social consequences of their storytelling" (Chase 2018, 553). Thus, research is a collaboration, where the researcher and participants collaborate as a form of researching with, rather than researching on (Clandinin 2016).

In the research I am currently conducting in my PhD fellowship, I explore how everyday life experiences of the climate crisis is storied in a local context through qualitative research with citizens in two Copenhagen neighbourhoods about their experiences of living in their local neighbourhood, of nature and climate change. Through interviews, photo elicitation (Harper 2002), walk-alongs (Kusenbach 2003), and workshops with the participants, I aim to explore how the climate crisis is experienced and storied by people in everyday life, in line with the ideas in the humanistic climate change research, presented earlier in this article.

Narrative inquiry may offer routes to understanding diverse stories and understandings of living in the climate crisis. Understanding experiences through narrative inquiry may help social scientists understand the differentiated ways in which we experience everyday life in a changing climate in different social, cultural, historical and geographical settings, due to the relational understanding of stories in narrative research that stories are always relational and composed and shaped by surroundings.

\section{Some limitations to stories}

Before turning to the conceptualisation of three insights that everyday life stories may offer climate change research, I will mention some limitations to working with stories. First, stories and storytelling do not, as mentioned, replace natural scientific work on climate change and, as it has been mentioned in urban studies, does not replace other tools (Sandercock 2003). What they do, is work in conjunction with what can be termed traditional disciplines and may enrich the understandings of the messy problems. Second, it is not possible to capture all the stories of the city's inhabitants and visitors and even if we 
were to know all the stories, we would still need to make sense of them through interpretation (Sandercock 2003, 12). The study of everyday life stories involves being reflexive to our gazes researchers and with what background we enter the field of study (Rose 1997; Alvesson and Sköldberg 2018). In addition, we must be critical and question the truth of the stories we hear, and be attentive to why some stories get told and others do not (Sandercock 2003). A third limitation to the study of stories is to do with storying and narrating not being the only human meaning-making process: "While it is true that humans are the only storytelling species and that stories often inform, inspire, teach, and guide, it is not true that humans think, speak, and bring meaning to their lives only through storytelling..." (Chase 2018, 548). A perspective that engage with other meaning-making processes and actions in everyday life in the climate crisis is practice-oriented research (e.g. Shove and Spurling 2013).

Everyday life stories and the climate crisis - three openings for change

Everyday life stories have the potential to enrich understandings of living with the climate crisis and possibilities for change, as they shine light on how we understand and communicate our experiences, ideas of the world, and abilities to respond to climate crisis. In the following, I present a conceptualisation of three openings for change that everyday life stories may bring: Insights into taken-for-granted-ness and explanations of actions, imaginings of alternative futures and retellings of stories through other perspectives. The following is based on works with stories from urban studies that is not defined as narrative inquiry. My aim with this conceptualisation is to show that this work provides openings change in climate change that resonates with the broader tradition of narrative inquiry.

Insights into taken-for-granted-ness and explanations of actions

Social scientists, including mobilities researchers have, as mentioned above, engaged in how movement and the interconnected, and sometimes entangled, networks are essential to social life and that cities and societies must be understood through these. One opening for change that stories may offer to social sciences is the taken-for-granted-ness of everyday life and explanations of actions. Freudendal-Pedersen has studied how everyday life mobilities practices are lived and told in Copenhagen. Her concept structural stories, illustrates how stories sometimes function as spoken continuations of the taken-forgranted activities in everyday life, as explanation and sometimes a defence of actions and as creators of paths for future actions (Freudendal-Pedersen 2009, 2015). Due to global risks, such as climate change, individuals must navigate the complex and messy problems in everyday life (Beck 2009; Giddens 2009), and individuals use stories to navigate.

What is particular about the structural stories is their occurrences across individuals' stories: "A structural story is a narrative that is spoken by many, and may be truer 
for some than it is for others" (Freudendal-Pedersen 2015, 33). Drawing on the works of among others, Giddens, Berger \& Luckmann and Fairclough, Jessop and Sayer, she describes how practices take part in the creation of discourses that become reified and institutionalised (Freudendal-Pedersen 2015). This way, the structural stories are “...understood and expressed as universal truths, and as such they create paths for mobilities praxis. The stories also reveal contradictions in the image of Copenhagen and the way that people actually live and move through the city" (Freudendal-Pedersen 2015, 31). The ambivalences made visible through the structural stories show the complexities of everyday life that include ambiguities between one's knowledge and actions and navigating in discrepancies as a daily practice (Freudendal-Pedersen 2015).

Freudendal-Pedersen's work on structural stories of mobilities practices in Copenhagen explores how stories function as a way to reveal, and perhaps remove, barriers to cycling or the irrationalities in terms of mobilities choices, such as driving a car despite knowledge of the environmental consequences (Freudendal-Pedersen 2009, 2015). Taking inspiration from Freudendal-Pedersen's structural stories, a colleague and I have studied coping strategies of climate change in everyday life (Bennetsen and Magelund 2015). Through qualitative interviews, we explored the differentiated stories of how Copenhageners cope with the risks of climate change in their everyday lives, which we analysed as four ideal types everyday life coping strategies. These coping strategies showed the paradoxes and irrationalities that the participants experienced when navigating their everyday life and the different explanations they would use for different actions (Bennetsen and Magelund 2015). As with the structural stories, the focus of our study was not on the actions, but on the stories that the participants gave as explanations and sometimes also as a defence of their daily actions. This work explored the different ways that the participants navigated and storied their everyday life in the climate crisis, creating insights into the rationalities and irrationalities when navigating daily life.

As mentioned, narrative inquiry research state that stories are lived, told, retold, and relived. The structural stories show how local 'truths' are retold and relived by a group of people, in other words reified and institutionalised. In studies of the climate crisis, the structural stories may help to understand the irrationalities of everyday life and thus create understandings of the everyday life complexities and ambivalences of living in the climate crisis, that may be vital in order to understand barriers for change in everyday life.

\section{Imaginings for alternative futures}

The second insight that I have chosen to present here, has to do with imaginings and formulations of alternative futures. Stories can be helpful in imagining change, alternatives to the present and our ideas of the future (Sandercock 2003). In her work in multicultural communities, Sandercock has found stories of hope to be helpful inspiration and that stories help to instil hope in settings where minorities have felt pessimistic about the 
future due to power relations and oppression (Sandercock 2003). Working with stories in everyday life, communities, planning, and social science may have potentials to work as catalysts for change as they can function as a source of inspiration and help people imagine alternative futures (Sandercock 2003, 26).

Whether in everyday life settings or in social scientific work, telling a story of how something might be, can help us imagine alternative futures. One kind of storying alternative futures is through scenarios. In his works with climate change, John Urry used scenarios as a way to grasp possible futures in climate change (Urry 2011). Urry does however write that scenario building "...makes it clear that there is no single best future" (Urry 2011, 141) because the achievement of one goal often will mean not achieving others.

Urry's works on scenario building involves knowledge of current trends and understandings of economic and social life processes. This kind of storying takes its departure from social science, and alternative futures might be imagined in other ways in everyday life. Grounding scenario imaginings and visualisations of different futures in everyday life experiences can be a useful way to engage research participants in envisioning different alternative futures, since the situated stories from different everyday life contexts differ. Different research methods are used to engage individuals in imagining alternative futures, such as the action research inspired methods future workshop or future scenario workshops (Nielsen 2006; Nielsen and Nielsen 2006). By creating free spaces for participants to discuss alternative futures, the workshops allow participants to critique the present and develop utopias that avoid what is criticised in the present. (FreudendalPedersen and Kesselring 2016). Here, alternative futures are developed and shared between a group of participants in a workshop, based on their individual and collective stories and experiences.

Utopias and dystopias can also help imaginings of alternative futures in fictional stories of possible futures in cities. An example of that can be found in the epilogue of the book The Granite Garden (Spirn 1984). Spirn concludes the book on the importance of planning cities with nature instead of ruling nature, with the description of two fictional visions of the future city: The infernal city and the celestial city (Spirn 1984). In two stories of future cities, the consequences of urban planning through domination of nature and enrichments of planning respecting nature, are manifested in the two distinct images of future cities: "In the present lies not only the nightmare of what the city will become if current trends continue, but also the dream of what the city could be" (Spirn 1984, 264). Alarmingly, a present-day reading of the book from 1984 brings to mind some resemblances between the infernal city and contemporary challenges in the climate crisis. The story of the celestial city, however, may spark hope as utopias are achievable if we nurture what we define as good. (Spirn 1984). The utopia becomes a tool, instead of a fictional fantasy, and utopias become a way to imagine futures through stories, by imagining other ways of living in or living with nature.

Stories in art and fictions that present alternative futures have been introduced in discussions of climate change and the future of cities (Swyngedouw 2010; Freudendal- 
Pedersen and Kesselring 2016) as potentials for envisioning futures in ways that are more connected to the everyday life and the human understandings of living in climate crisis. There are numerous examples of fictional stories that enables imaginings of alternative futures, but art may also work as ruptures (Bech-Jørgensen 1994) in everyday life that enables us to tell different stories about futures. Different artistic interventions have been used to situate climate change into everyday places to raise awareness and imagine alternative futures. One example is the work Ice Watch by the artist Olafur Eliasson (Eliasson 2019). Marking the publication of IPCC's fifth assessment report on climate change, Eliasson placed twelve large blocks of Greenlandic ice in front of the Copenhagen City Hall in October 2014, to provide "... a direct and tangible experience of the reality of melting arctic ice" (Eliasson 2019). The blocks of ice told the story of the grand challenges of global warming. Such interventions may function as a starting point for telling stories of the climate crisis and imagining futures that do not entail enormous amounts of ice melting due to climate change, as they interrupt the everyday life experiences and encourage other stories of futures.

The imaginings of alternative futures in climate crisis through stories and storytelling may serve as a catalyst for change, as it enables us to question what we take for granted in the present and what might be different in the future. Reading, hearing, seeing or being asked to formulate alternative futures, be it from our everyday life or fiction or art, may inspire us to tell different stories of what the future might look like and thus inspire change.

\section{Retellings of stories through other perspectives}

When imagining alternative futures, we may become capable of retelling the stories of the past and the present. Stories have the possibilities to change our perspectives on the present world, events, and the dominant stories created by others. The third opening that stories may bring to social scientific climate change research concerns the ability to retell stories through other perspectives that become visible when engaging in the stories and storytelling of others. As mentioned earlier, engaging in stories may help us, researchers as well as participants, become reflexive about which stories are retold, and which are silenced, what the dominant stories of climate change are and why.

When stories are understood as constructive of reality, they hold the potential to challenge, retell or deconstruct dominant stories. Sandercock has worked with possibilities to retell stories of the past: "In telling new stories about our past, our intention is to reshape our future" (Sandercock 2003, 22). This third opening through stories explores how we may formulate other stories than the dominant stories of planning (Sandercock 2003) or responses to climate change (Fjalland 2019). The argument is that no stories encompass every aspect, and that (dominant) stories leave out perspectives of the embodied, situated experiences of anyone other than the tellers of the stories. This opening draws on the idea of strong objectivity, presented by Harding, that value the perspective of the 
other and be critical of the positions implied (Højgaard 2007, 267). By hearing the stories of others, we may gain new insights, and though never be able to know all stories (Højgaard 2007), we may become aware of other stories and perspectives and thus capable of doing something different.

An example from the Copenhagen area, is the work of Fjalland (2019). Inspired by the works of le Guin and Fisher, with her research Fjalland seeks to tell another story about how we are able to live with nature. In her work, she explores how we can become able to respond to environmental questions, through studying the practices and stories of people that act in response to climate change. These actions provide another perspective than what has been mentioned as a political hesitation on climate change (Nielsen and Bislev 2018). Fjalland's ethnographic fieldwork centres around the stories of circulations of food and waste between restaurants and farms, and her site of study moves between the urban context of Copenhagen and a rural context outside the city (Fjalland 2019). Moving between the city and the countryside expands the understanding of the connectedness and entanglements in the climate crisis between the city and countryside and between humans and nonhumans:

"We must search for languages that hold words and stories that spur the imagination for reparative futures and response-ability; of care, collaboration and compassion; and we must tell many different stories, track down old stories, and re-tell them (Gibson et. Al 2015). We must nurture the capacity of being able to imagine and tell stories that push us to question how else life could be like (Vannini \& Taggart 2015, 18) and search for stories that invite us to rethink what our futures might feel like" (Fjalland 2019, 60-61).

Stories are essential to the way we understand the past, present, and future. In the climate crisis, listening to stories of other ways of being in the world and retelling our familiar stories of humans and nature might spur other understandings of what it means to live with climate change and how we might live differently. Studying the actions and stories of the other may enrich our understandings of what the story of the climate crisis is, and how we can cope with it.

\section{Conclusion}

Stories shape the way we live and understand the world. The stories of the lived experiences of an unusually hot summer, increasing sea levels and other aspects of climate change intermingle with our everyday lives, just as policies and global processes do. Stories are important as they may inspire reflection, imagination and action and create new realities. These manifold possibilities of stories reflect a collecting power of sharing, bringing people together, and shaping new collective stories (Sandercock 2003). Just as 
stories and narratives are a way of creating meaning for individuals in everyday life, core stories of a group of people can "...give meaning to our collective life" through shared meaning (Sandercock 2003, 16). Living in the climate crisis is a collective condition and listening to the stories of others may enrich social scientific research with situated perspectives of this condition and what change can be.

In seeking to understand the complex and sometimes irrational problems precipitated by climate change, social science must explore the mundane and tacit forms of knowledge of everyday life further. I will conclude this article by arguing that despite the limitations of exploring with stories, everyday life stories offer nuances and perspectives on situated experiences and an understanding of living in the climate crisis and openings for change. These perspectives are not meant as arguments for further responsibility to be placed on individuals, but for situated insights to be further included in policy making and social scientific research on climate change. Everyday life stories may enrich understandings of the multiple, complex, and differentiated experiences of everyday life, and how the climate crisis is experienced, understood, and managed, through their abilities to spur imaginings and curiosity. The three openings that I have presented here, illuminate different aspects of how stories may help us understand human experiences and responses in the climate crisis; explore (some of) the taken-for-granted-ness and explanations of everyday life actions, enable imaginings of futures that are different from the present and spur inspiration for other ways of being in the world - aspects that may enrich social scientific studies of the climate crisis further.

\section{Literature}

Alvesson, M. and Sköldberg, K. (2018). Reflexive methodology, new vistas for qualitative research. Third ed. Los Angeles: Sage.

Bech-Jørgensen, B. (1994). Når hver dag bliver hverdag. Copenhagen: Akademisk Forlag.

Beck, U. (2009). World at Risk. Polity Press.

Bee, B. A., Rice, J. and Trauger, A. (2015). A Feminist Approach to Climate Change Governance: Everyday and Intimate Politics, Geography Compass, vol. 9(6), pp. 339-350. https://doi.org/10.1111/gec3.12218.

Bennetsen, N. M. and Magelund, J. O. (2015). Hverdagshåndteringer - En undersøgelse af boeredygtighed og mobilitet $i$ hverdagslivet. Roskilde Universitet.

Chase, S. E. (2018). Narrative inquiry: Toward theoretical and methodological maturity. In: Denzin, N. K. and Lincoln, Y. S. eds., The Sage Handbook of Qualitative Research, 5th ed. Thousand Oaks: SAGE, pp. 546-560.

Clandinin, D. J. (2016). Engaging in Narrative Inquiry. Abingdon, Oxon: Routledge. https://doi.org/10.4324/9781315429618.

Danish Meteorological Institute (2018). Vejret i Danmark - sommer 2013. Available at: 
https://www.dmi.dk/fileadmin/user_upload/Afrapportering/Saesonoversigter/so mmer18.pdf.

Denzin, N. K. (2001). The reflexive interview and a performative social science. Qualitative Research, vol. 1(1), pp. 23-46.

Egmose, J. (2015). Action Research for Sustainability: Social Imagination Between Citizens and Scientists. Farnham: Ashgate.

Eliasson, O. (2019). Ice Watch @ olafureliasson.net. Available at: https://olafureliasson.net/archive/artwork/WEK109190/ice-watch [Accessed: 13 May 2019].

Eskjær, M. F. and Sørensen, M. (2014). Introduktion - Humanistisk klimaforskning. In: Sørensen, M. and Eskjær, M. F. eds., Klima og mennesker - Humanistiske perspektiver på klimaforandringer, Copenhagen: Museum Tusculanums Forlag, pp. 11-26.

Fischer, F. and Forester, J. (1993). The argumentative turn in policy analysis and planning. Durham: Duke University Press. https://doi.org/10.1215/ 9780822381815.

Fischer, Frank and Gottweis, H. (2012). Introduction. In: Fischer, Frank; and Gottweis, H. eds., The Argumentative Turn Revisited. Public Policy as Communicative Practice. Durham \& London: Duke University Press, pp. 1-27. https://doi.org/10.1215/9780822395362.

Fjalland, E. L. P. (2018). A Carrier Bag Story of (waste) food, hens and the sharing economy, Applied Mobilities. Routledge, vol. 3(1), pp. 34-50. https://doi.org/10.1080/23800127.2018.1435439.

Fjalland, E. L. P. (2019). Rebellious waste \& food, searching for reparative futures within urban-rural landscapes. Roskilde University. Available at: https://rucforsk.ruc.dk/ws/files/65098107/e_Afhandling_Emmy_Fjalland_1_.pdf

Fjalland, E. L. P., Freudendal-Pedersen, M. and Hartmann-Petersen, K. (2017). Networked Urban Mobilities: Practices, Flows, Methods. In: FreudendalPedersen, M., Hartmann-Petersen, K., and Fjalland, E. L. P. eds., Experiencing Networked Urban Mobilities. Routledge, pp. 1-9. https://doi.org/10.4324/9781315200255.

Frank, A. W. (2012). Letting Stories Breathe. Chicago: University of Chicago Press. 10.7208/chicago/9780226260143.001.0001.

Freudendal-Pedersen, M. (2009). Mobility in daily life, between freedom and unfreedom. Farnham, Surrey: Ashgate.

Freudendal-Pedersen, M. (2014). Ethics and Responsibilities. In: Adey, P. et al. eds., The Routledge Handbook of Mobilities. London: Routledge, pp. 143-53. https://doi.org/10.4324/9781315857572.

Freudendal-Pedersen, M. (2015). Cyclists as Part of the City's Organism: Structural Stories on Cycling in Copenhagen. City \& Society, vol. 27(1), pp. 30-50. doi: https://doi.org/10.1111/ciso.12051.

Freudendal-Pedersen, M. and Kesselring, S. (2016). Mobilities, Futures \& the City: 
repositioning discourses - changing perspectives - rethinking policies. Mobilities, vol. 11(4), pp. 575-586. https://doi.org/10.1080/17450101.2016.1211825.

Freudendal-Pedersen, M. and Kesselring, S. (2018). Networked Urban Mobilities. In: Freudendal-Pedersen, M. and Kesselring, S. eds., Exploring Networked Urban Mobilities - Theories, Concepts, Ideas. New York: Routledge, pp. 1-18. https://doi.org/10.4324/9781315201078.

Gibson, K., Rose, D. B. and Fincher, R. (2015). Manifesto for Living in the Anthropocene. Brooklyn, New York: punctum books. doi.org/10.21983/P3.0100.1.00.

Giddens, A. (2009). The politics of climate change. Cambridge: Polity Press.

Graham, S. and Marvin, S. (2001). Splintering Urbanism. London: Routledge. https://doi.org/10.4324/9780203452202.

Gubrium, J. F. and Holstein, J. A. (2009). Analyzing Narrative Reality. Thousand Oaks: SAGE Publications, Inc. https://dx.doi.org/10.4135/9781452234854.

Le Guin, U. K. (2007). What Makes a Story, Ursula K. Le Guin Website. Ursula K. Le Guin Website. Available at: http://www.ursulakleguin.com/WhatMakesAStory.html [Accessed: 10 May 2019].

Haraway, D. (1988). Situated Knowledges: The Science Question in Feminism and the Privilege of Partial Perspective. Feminist Studies, vol. 14(3), pp. 575-599. doi.org/10.2307/3178066.

Harper, D. (2002). Talking about pictures: A case for photo elicitation. Visual Studies, vol. 17(1), pp. 13-26.

Hartmann-Petersen, K. (2009). I medgang og modgang - Fleksibilitet og flygtighed $i$ buschaufførers mobile liv. Roskilde Universitet.

Healey, P. (1993). Planning Through Debate: The Communicative Turn in Planning Theory. In: Fischer, F. and Forester, J., eds., The Argumentative Turn in Policy Analysis and Planning. London: Duke University Press, pp. 233-253. https://doi.org/10.1215/9780822381815.

Højgaard, L. (2007). Feministisk videnskabsfilosofi. In: Søndergaard, D. M., ed., Feministiske toenkere - en tekstsamling. Copenhagen: Hans Reitzels Forlag.

Kusenbach, M. (2003). Street Phenomenology: The Go-Along as Ethnographic Research Tool. Ethnography, vol. 4(3), pp. 455-485. https://doi.org/10.1177/ 146613810343007.

Moezzi, M., Janda, K. B. and Rotmann, S. (2017). Using stories, narratives, and storytelling in energy and climate change research. Energy Research and Social Science, vol. 31(September), pp. 1-10. https://doi.org/10.1016/j.erss.2017. 06.034 .

Nielsen, A. B. and Bislev, S. A. (2018). Et syn for sagen: En analyse af videnskab, materialitet og erfarings betydning for Københavns klimatilpasningspolitik. Politik, vol. 21(1), pp. 59-78. https://doi.org/10.7146/politik.v21i1.106143.

Nielsen, K. A. and Nielsen, B. S. (2006). Methodologies in Action Research. In: Nielsen, K. A. and Svensson, L., eds., Action Research and Interactive Research: Beyond 
practice and theory. Maastricht: Shaker Publishing.

Nielsen, L. D. (2006). The Methods and Implication of Action Research. In: Nielsen, K. A. and Svensson, L., eds., Action Research and Interactive Research: Beyond practice and theory. Maastricht: Shaker Publishing.

Paschen, J.-A. and Ison, R. (2014). Narrative research in climate change adaptation Exploring a complementary paradigm for research and governance. Research Policy, vol. 43(6), pp. 1083-1092. https://doi.org/10.1016/j.respol.2013.12.006.

Pink, S. (2012). Situating everyday life: Practices and places. London: SAGE. http://dx.doi.org/10.4135/9781446250679.

Rose, G. (1997). Situating knowledges: positionality, reflexivities and other tactics. Progress in Human Geography, vol. 21(3), pp. 305-320. https://doi.org/10.1191\%2F030913297673302122.

Rüegg, P. (2019). Simultaneous heatwaves caused by anthropogenic climate change. Eidgenössische Technische Hochschule Zürich News (9 April). Available at: https://www.ethz.ch/en/news-and-events/eth-news/news/2019/04/simultaneousheatwaves-caused-by-anthropogenic-climate-change.html.

Sandercock, L. (2003). Out of the closet: The importance of stories and storytelling in planning practice. Planning Theory \& Practice, vol. 4(1), pp. 11-28. https://doi.org/10.1080/1464935032000057209.

Sheller, M. and Urry, J. (2006). The New Mobilities Paradigm. Environment and Planning A, vol. 38(2), pp. 207-226. https://doi.org/10.1068\%2Fa37268.

Shove, E. and Spurling, N. eds., (2013). Sustainable Practices - Social Theory and climate change. Abingdon, Oxon: Routledge. https://doi.org/10.4324/97802030 71052 .

Sørensen, M. and Eskjær, M. F. (2014). Klima og mennesker - Humanistiske perspektiver på klimaforandringer. Copenhagen: Museum Tusculanums Forlag.

Spirn, A. W. (1984). The Granite Garden - Urban Nature and Human Design. Basic Books.

Swyngedouw, E. (2010). Apocalypse Forever? - Post-political Populism and the Spectre of Climate Change. Theory, Culture \& Society, vol. 27(2-3), pp. 213-232.

Urry, J. (2000). Sociology beyond Societies - Mobilities for the twenty-first century. London: Routledge. https://doi.org/10.4324/9780203021613.

Urry, J. (2007). Mobilities. Cambridge: Polity Press.

Urry, J. (2011). Climate Change \& Society. Polity Press. 